\title{
Premature elevation in serum insulin-like growth factor-I advances first ovulation in rhesus monkeys
}

\author{
M E Wilson \\ Yerkes Primate Research Center of Emory University, 2409 Taylor Lane, Lawrenceville, Georgia 30043, USA \\ (Requests for offprints should be addressed to M E Wilson)
}

\begin{abstract}
Previous data suggest that developmental increases in peripheral concentrations of insulin-like growth factor-I (IGF-I) may be one of several neuroendocrine signals that regulate the timing of puberty. In order to test this hypothesis further, normal juvenile female rhesus monkeys (Con; $n=6$ ) were compared with age-matched animals (Igf; $n=4)$ which received a constant subcutaneous infusion of recombinant human IGF-I $(110 \mu \mathrm{g} / \mathrm{kg} /$ day $)$ from 18 through 36 months of age. Menstrual bleeding was monitored and ovulation was inferred from a sustained rise in serum progesterone. In order to assess the sensitivity of luteinizing hormone-releasing hormone (LHRH) neurons to excitation, the response of serum LH to the acute administration of the glutamate receptor agonist N-methyl-D, L-aspartic acid (NMDA) was assessed prior to menarche, 2 months following menarche, and during the follicular phase of a female's third ovulation or 50 days after a female's first ovulation. In addition, the pituitary response of LH secretion to an LHRH agonist was assessed during the follicular phase of a female's fourth ovulation or 75 days following her first ovulation.

IGF-I treatment effectively elevated serum concentrations by more than $86 \%$ of the values observed in Con animals. Although the treatment also enhanced the developmental increase in IGF binding protein-3 (IGFBP-3), IGF-I was increased proportionately more, resulting in a significantly higher molar ratio of IGF-I:IGFBP-3 in treated females throughout the course of the study. Treatment with IGF-I did not affect age at menarche but did significantly advance the age of first ovulation.
\end{abstract}

Consequently, the interval between menarche and first ovulation was significantly shorter in Igf compared with Con females. Although the total number of ovulations exhibited by $\operatorname{Igf}(3 \cdot 8 \pm 0 \cdot 3)$ and Con females $(3 \cdot 0 \pm 0 \cdot 5)$ in the 12 months following menarche was similar, significantly more of these were characterized by normal luteal phase progesterone secretion in Igf $(100 \% \pm 0)$ compared with Con females $(64 \% \pm 17)$. An analysis of cycles with a normal luteal phase revealed that serum estradiol during the luteal phase was significantly higher in Igf compared with Con females. Finally, IGF-treated females responded to NMDA treatment with a significantly greater increase in serum LH following menarche but not prior to menarche. In contrast, the response of serum LH to an LHRH agonist did not differ between Igf and Con females.

These data suggest that the premature elevation in IGF-I levels, and consequently the ratio of IGF-I:IGFBP-3, accelerates the tempo of the final stages of puberty in rhesus monkeys. This action of IGF-I is probably the result of an increase in LHRH neuronal activity and is not due to a change in pituitary sensitivity to LHRH stimulation. In addition, ovarian sensitivity to LH stimulation during the luteal phase is also increased by IGF-I. Taken together, these data suggest that developmental increases in peripheral IGF-I secretion participate in the neuroendocrine regulation of puberty in female primates.

Journal of Endocrinology (1998) 158, 247-257

\section{Introduction}

Although the developmental pattern of luteinizing hormone releasing hormone (LHRH) and luteinizing hormone (LH) secretion is well documented (Terasawa et al. 1984, Watanabe \& Terasawa 1989), the neuroendocrine mechanisms which re-establish pulsatile LHRH and, consequently, LH secretion during primate puberty are not fully understood. Following a brief neonatal activation of the hypothalamic-pituitary-ovarian axis
(Plant 1986), a prolonged hypogonadotropic state ensues, characterized by low amplitude, infrequent pulses of LHRH and LH (Watanabe \& Terasawa 1989). This hypogonadotropism may be the result of either an absence of stimulatory input to or an active inhibition of the LHRH neuronal system (see Terasawa 1995 for review). However, it is clear that this juvenile condition is not due entirely to gonadal steroid negative feedback inhibition. Although ovariectomy during this phase results in a slight increase in nocturnal LHRH (Chongthammakun et al. 
1993) and LH release (Pohl et al. 1995), open loop secretion of these peptides (Terasawa et al. 1984, Winter et al. 1987) gradually increases and only reaches agonadal, adult-like concentrations at an age when menarche would be expected (Wilson 1989). Once LHRH and LH secretion is re-established, estradiol negative feedback inhibition becomes functionally important regulating further increases in these peptides. Indeed, the later stages of puberty in female primates is characterized by a decreasing sensitivity to estradiol negative feedback inhibition of LH secretion (Rapisarda et al. 1983, Wilson 1995) such that the timing of this loss in hypersensitivity to estradiol negative feedback sets the tempo of puberty and determines the occurrence of first ovulation.

Recent evidence has suggested that signals from the growth process, specifically growth hormone (GH)dependent increases in insulin-like growth factor-I (IGF-I), may facilitate developmental increases in LHRH and $\mathrm{LH}$ secretion during the final stages of puberty. In data derived from peri-pubertal rats, IGF-I stimulates the in vitro release of LHRH from the median eminence (Hiney et al. 1991), and increases in serum IGF-I stimulate IGF receptor mRNA in the median eminence (Hiney et al. 1996). Furthermore, the stimulation of LH release by the central administration of IGF-I is blocked by the immunoneutralization of LHRH in immature rats (Hiney et al. 1996). In monkeys, the long-term administration of GH accelerates (Wilson et al. 1989) while the inhibition of endogenous GH and IGF-I release by a somatostatin analog delays (Wilson \& Tanner 1994) the occurrence of first ovulation. However, neither treatment regimen affects age at menarche. Clinical observations indicate that GH deficiency is associated with delayed puberty (OgilvyStuart \& Shalet 1992) and GH replacement accelerates the completion of puberty once it has begun (Darendelier et al. 1990, Stanhope et al. 1992). These data suggest that the importance of the $\mathrm{GH}$ axis in the development of LHRH and LH secretion in primates may be restricted to the later stages of puberty, specifically to changes in gonadal steroid negative feedback. Indeed, the long-term administration of IGF-I accelerates the loss of hypersensitivity to estradiol negative feedback inhibition of LH secretion in adolescent monkeys (Wilson 1995). However, these data implicating a role for IGF-I in the development of LHRH secretion must be balanced against observations that IGF-I may inhibit LHRH-stimulated release from hypothalamic explants (Bourguinon et al. 1993) and that manipulations of endogenous IGF-I concentrations do not affect timing of vaginal opening in rats (Gruaz et al. 1994, 1997).

In order to evaluate further the role of IGF-I in regulating developmental increases in $\mathrm{LH}$ secretion, juvenile female rhesus monkeys receiving a continuous subcutaneous infusion of IGF-I in order prematurely to elevate peripheral concentrations, were compared with age-matched controls. The working hypothesis was that a significant elevation in serum IGF-I concentrations would accelerate age at first ovulation and that this effect would be due to an augmentation of LH secretion and not necessarily to a change in ovarian responsiveness to gonadotropin stimulation induced by IGF-I (Giudice 1992). To define further how IGF-I may affect the activity of LHRH neurons and pituitary responsiveness, the response of $\mathrm{LH}$ release to the acute administration of the glutamate receptor agonist N-methyl-D, L-aspartic acid (NMDA; Brann 1995) and to an LHRH agonist were evaluated. The results of the study suggest that the premature elevation in peripheral IGF-I concentrations accelerates the occurrence of first ovulation by increasing the responsiveness of LHRH neurons and by an augmentation of $\mathrm{LH}$ secretion.

\section{Materials and Methods}

\section{Subjects}

Subjects were female rhesus monkeys (Macaca mulatta), born and raised at the Yerkes Primate Research Center of Emory University. Animals were socially housed indoors in large cages (4 per cage) under a $12 \mathrm{~h}$ light: $12 \mathrm{~h}$ darkness cycle and a constant temperature range of $22-25^{\circ} \mathrm{C}$ as described previously (Wilson et al. 1988). Animals were fed commercial monkey chow (Harlan Teklan Monkey Diet, Madison, WI, USA), available ad libitum, twice daily, fresh fruit once daily, and had continuous access to water. Food was given in sufficient quantity so that all animals could eat to satiety. The experimental protocol was approved by the Emory University Animal Care and Use Committee in compliance with all NIH and USDA Standards.

\section{Procedures}

Animals were studied from 18 months of age through their fourth ovulation or 36 months of age, whichever occurred first. Females were randomly assigned to a control group (Con; $n=6$ ) or to a treatment group (Igf; $n=6$ ) that received a constant, subcutaneous (s.c.) infusion of recombinant human (h) IGF-I (Genentech Inc., South San Francisco, CA, USA) at a dose of $110 \mu \mathrm{g} / \mathrm{kg} /$ day. These infusions were accomplished with Alzet osmotic mini-pumps (Alza Corp., Palo Alto, CA, USA) which were implanted s.c., under sterile conditions, between the scapula while the animals were under general anesthesia (Telazol; $4 \mathrm{mg} / \mathrm{kg}$ intramuscularly). The IGF-I was supplied pre-diluted in bacteriostatic water with benzyl alcohol as a preservative. Further dilutions were made with bacteriostatic water. Preparation of the pump followed the manufacture's directions. Using sterile techniques, the IGF-I solution was drawn into a calibrated $3 \mathrm{ml}$ syringe. The pump reservoir averaged $2 \cdot 18 \pm 0 \cdot 04 \mathrm{ml}$. The pump 


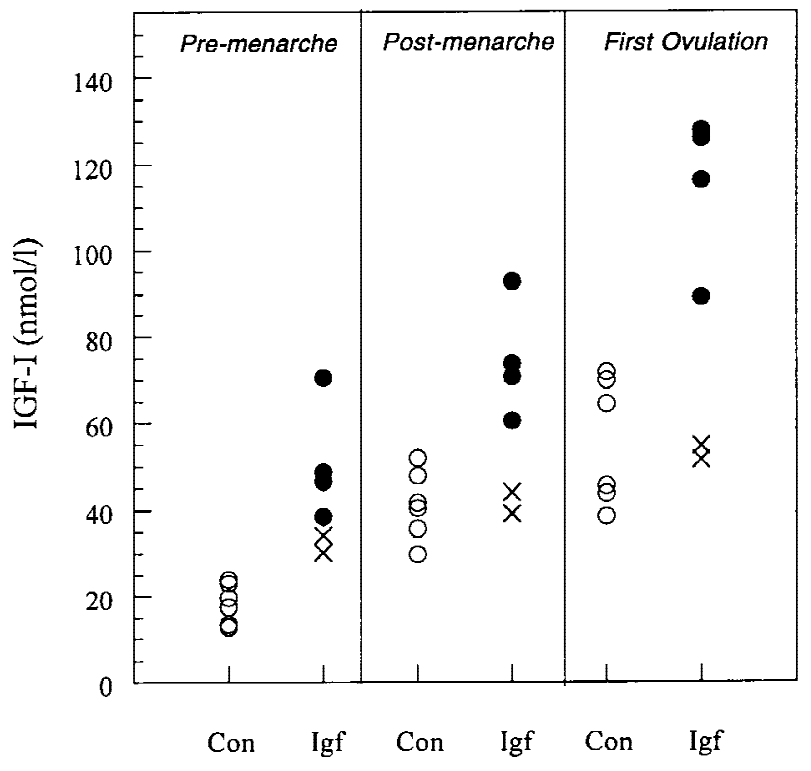

Groups at Three Developmental Stages

Figure 1 Individual distribution of serum IGF-I concentrations at three developmental stages for untreated, control females (Con) and females receiving a constant, s.c. infusion of IGF-I (Igf). The Igf females were further subdivided into those whose serum IGF-I levels were elevated $(\mathbf{)})$ and those whose serum levels were not elevated $(\mathrm{X})$ by the treatment.

was slowly filled with $2 \cdot 2 \mathrm{ml}$ solution until a small bead of solution appeared at the opening of the reservoir. After inserting the flow modulator into the pump, it was incubated in sterile saline at $24{ }^{\circ} \mathrm{C}$ for $3 \mathrm{~h}$ before implantation.

Pumps were changed every 28 days or more frequently if needed. The dose used was chosen to elevate serum IGF-I approximately 100\% compared with untreated, age-matched controls (Wilson 1995). In order adequately to test the hypothesis that peripheral elevations of IGF-I levels advance maturation, the efficacy of the treatments was critical. Consequently, serum concentrations of IGF-I were determined periodically to ensure that levels were elevated to the desired range. As illustrated in Fig. 1, this assessment revealed that two of the IGF-I-treated females consistently had serum IGF-I concentrations that were lower than the other IGF-treated females and, at later developmental ages, in the same range as the untreated, Con females. Serum IGF-binding protein-3 (IGFBP-3) concentrations were similarly reduced. Since this did not meet the criteria of the treatment, the data from these two Igf females were not included in the analysis. Indeed, the age at first ovulation for these two non-responding females was $32 \cdot 8 \pm 0 \cdot 9$ months, similar to that of the Con females (see Results). Finally, the IGF-I-treated females were equally distributed throughout the 3 caging units $(2$ per cage) and the relative social ranks of the treated females, based on agonistic interactions, were as follows: cage 1: 2 and 4; cage 2: 1 and 2; cage 3: 3 and 4 (with 1 being the most socially dominant).

Blood samples were collected weekly through 20 months of age and twice weekly thereafter using procedures previously described (Wilson et al. 1988). Samples were assayed for progesterone, estradiol, IGF-I, and IGFBP-3. Ovulation was inferred from an elevation $(>3.18 \mathrm{nmol} / \mathrm{l})$ of serum progesterone that was sustained for more than 10 days. Short luteal phase ovulations were inferred from serum progesterone values that were sustained for less than 10 days. Typically, these luteal phases are also characterized by diminished peak serum progesterone, and were defined as inadequate luteal phases. Short, inadequate luteal phases are typically associated with deficits in follicular maturation due to abnormal gonadotropin secretion (Wilks et al. 1979). Animals were inspected daily for menstruation to document menarche and to assist in calculating the length of the luteal phase (rise in serum progesterone to menstruation). Each female was weighed monthly.

At three specific developmental periods: pre-menarche ( 20 months of age), 4 months post-menarche, and during either the peri-ovulatory phase of their third ovulation or 50 days after their first ovulation, a female's response to the glutamate receptor agonist NMDA was assessed. Repeated administration of NMDA elicits a sustained increase in LH in juvenile male monkeys (Gay \& Plant 1987). The acute administration of NMDA results in an increase in serum LH if the pituitary has been stimulated previously by LHRH; otherwise, little LH is released following NMDA (Gay \& Plant 1987). Thus, if IGF-I is having an effect on LHRH neurons, LH secretion should be enhanced in IGF-I-treated compared with untreated subjects following the acute administration of NMDA. At each assessment, females received $5 \mathrm{mg}$ NMDA/ $\mathrm{kg}$ intravenously (Sigma Chemical Corp., St Louis, MO, USA) at time 0 and again at +60 min following the first treatment. Blood samples were collected every $20 \mathrm{~min}$ for $60 \mathrm{~min}$ preceding and $120 \mathrm{~min}$ following the first NMDA treatment. Serum samples were assayed for LH. In addition, changes in serum LH following treatment with an LHRH analog (Lupron, leuprolide acetate; TAP Pharmaceuticals, Deerfield, IL, USA) was assessed to determine if IGF-I affected pituitary responsiveness to LHRH. During the follicular phase of her fourth ovulation or 75 days following her first ovulation, each female received a s.c. bolus injection of Lupron $(14 \mu \mathrm{g} / \mathrm{kg}$; Ibanez et al. 1994) and serum samples were collected at $-24 \mathrm{~h},-12 \mathrm{~h}$, and just prior to treatment, and at $3,6,9,12,24$, and $48 \mathrm{~h}$ following treatment and were assayed for $\mathrm{LH}$.

\section{Analyses}

All samples were assayed in duplicate. Each assay contained samples from all females for a specified time period. 
Serum concentrations of estradiol and progesterone were determined by radioimmunoassay (RIA), using commercially available reagents (Diagnostic Products Corp., Los Angeles, CA, USA) as described previously (Wilson et al. 1988). The estradiol assay used $200 \mu \mathrm{l}$ serum and had a sensitivity of $5-7 \mathrm{pmol} /$ tube $(25 \mathrm{pmol} / \mathrm{l})$ and an upper limit of $200 \mathrm{pmol} /$ tube $(1000 \mathrm{pmol} / \mathrm{l})$. Intra-assay coefficients of variation were $<4 \%$ while the interassay coefficient of variation at the midpoint of the standard curve was $12 \cdot 5 \% \pm 0 \cdot 8(n=50)$. For progesterone, $250 \mu \mathrm{l}$ serum were extracted by $2 \mathrm{ml}$ of an ether:hexane (9:1) system with the solvent layer evaporated under $\mathrm{N}_{2}$ and reconstituted in assay diluent. Extraction efficiencies were calculated in every assay using the amount of ${ }^{125}$ I-progesterone recovered $(>95 \%)$. Sample concentrations were corrected by the extraction efficiency. The assay used $50 \mu \mathrm{l}$ equivalents and had a sensitivity of $0.06 \mathrm{nmol} /$ tube $(1.2 \mathrm{nmol} / \mathrm{l})$ and an upper limit of $12 \mathrm{nmol} /$ tube $(240 \mathrm{nmol} / \mathrm{l})$. Intra-assay coefficients of variation were $<4 \%$ while the interassay coefficient of variation at the midpoint of the standard curve was $11 \cdot 5 \% \pm 0 \cdot 4(n=62)$. Total serum concentrations of IGF-I were determined, following acid extraction of $100 \mu \mathrm{l}$ serum, using an RIA validated for the monkey (Osterud et al. 1986). The assay used hIGF-I (Peninsula Labs, Belmont, CA, USA) as reference material and for iodination and a polyclonal anti-IGF-I antibody (National Hormone and Pituitary Program, NIDDK, USDA). Assuming a molecular mass of $7 \cdot 5 \mathrm{kDa}$, concentrations of IGF-I were converted to nmol/l. The assay used $5 \mu \mathrm{l}$ equivalents of reconstituted extract and had a sensitivity of $5 \mathrm{pmol} /$ tube $(1 \mathrm{nmol} / \mathrm{l})$ and an upper limit of $1333 \mathrm{pmol} /$ tube $(266 \mathrm{nmol} / \mathrm{l})$. Intra-assay coefficients of variation were $<5 \%$ while the interassay coefficient of variation at the midpoint of the standard curve was $6 \cdot 9 \% \pm 0 \cdot 4 \quad(n=19)$. Concentrations of IGFBP-3 were measured by a commercially available immunoradiometric assay (Diagnostic Systems Laboratory, Webster, TX, USA). In order to minimize protein degradation and protease activity producing IGFBP-3 fragments, previously unthawed samples were assayed for IGFBP-3. Assuming a molecular mass of $27.5 \mathrm{kDa}$ (reflecting the non-glycosylated form), concentrations of IGFBP-3 were converted to nmol/l. The assay used $5 \mu \mathrm{l}$ serum and had a sensitivity of $3.3 \mathrm{pmol} / \mathrm{tube}(0.7 \mathrm{nmol} / \mathrm{l})$ and an upper limit of $1750 \mathrm{pmol} /$ tube $(350 \mathrm{nmol} / \mathrm{l})$. Intra-assay coefficients of variation were $<5 \%$ while the interassay coefficient of variation was $20 \cdot 3 \% \pm 0 \cdot 9(n=7)$. Serum LH concentrations were determined by RIA which used recombinant monkey $\mathrm{LH}$ as the reference material and for iodination and a monoclonal antibody to monkey $\mathrm{LH}$ (Xiao et al. 1994, National Hormone and Pituitary Program, NIDDK, USDA). The assay used 100-200 $\mu \mathrm{l}$ serum and had a sensitivity of $0.03 \mathrm{ng} /$ tube $(0 \cdot 15-0.30 \mathrm{ng} / \mathrm{ml})$ and an upper limit of $0.7 \mathrm{ng} /$ tube $(7-14 \mathrm{ng} / \mathrm{ml})$. Intraassay coefficients of variation were $<6 \%$ while the

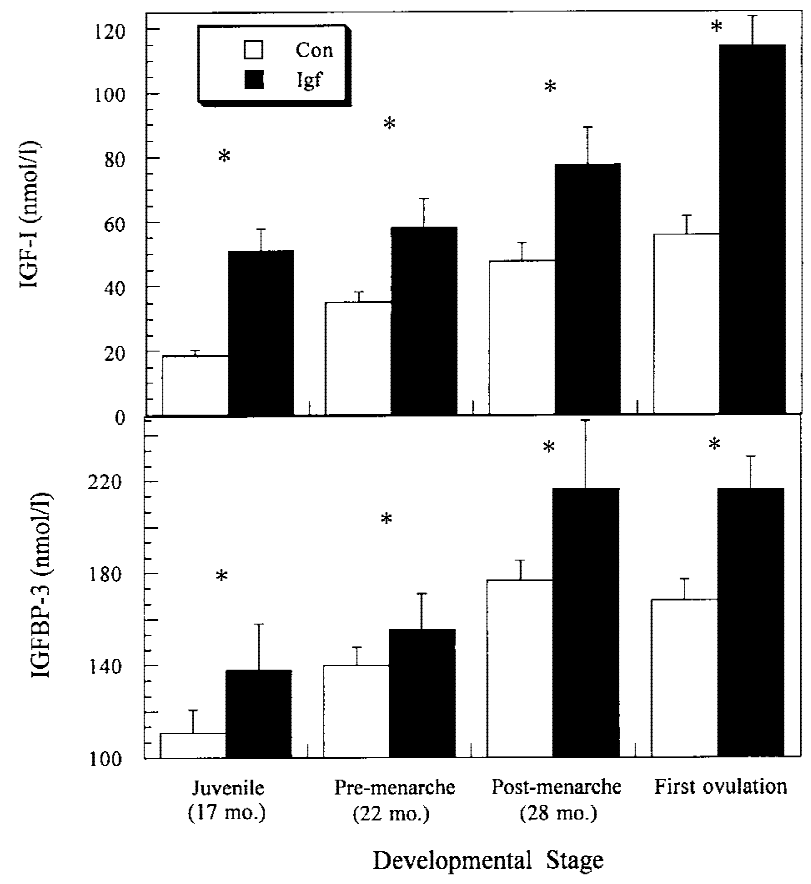

Figure 2 Mean ( \pm S.E.M.) serum levels of IGF-I (upper panel) and IGFBP-3 (lower panel) at four developmental stages in untreated control females (Con; $n=6$ ) and females receiving a constant, s.c. infusion of IGF-I (Igf; $n=4)$ ). ${ }^{*}<<0.05$ Igf compared with Con at that time point. mo, months.

interassay coefficient of variation at the midpoint of the standard curve was $11 \cdot 9 \% \pm 0.9(n=37)$.

Data are expressed as means \pm S.E.M. for each group. Differences between Con and Igf groups over time were evaluated with a two-way analysis of variance for repeated measures (SPSS for the Macintosh; Chicago, IL, USA) with treatment (control vs IGF-I treated) as the main effect and advancing age or time as the repeated effect. Specific, post-hoc comparison's were made with the Fisher's LeastSquare Difference test. Differences between simple means (non-repeated, single measures) were evaluated with $t$-tests. Statistical tests that yielded a value of $P<0.05$ were considered to be significant. Given the small sample size (Con; $n=6$ and Igf; $n=4$ ), estimates of power were also calculated for specific statistical comparisons.

\section{Results}

\section{Efficacy of IGF-I treatment}

Continuous infusion with IGF-I elevated serum concentrations of IGF-I above those of Con females (Fig. 2, upper panel). Developmental increases were evident in serum IGF-I concentrations in Con females as well as Igf females $\left(\mathrm{F}_{3,24}=34 \cdot 22\right)$. Overall, the percentage increase in mean serum IGF-I for the Igf females was $86 \%( \pm 15)$ above the 


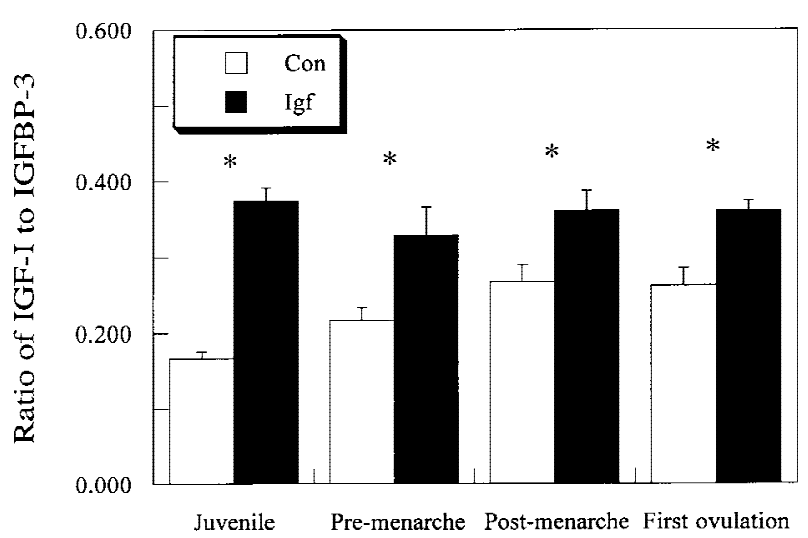

Figure 3 Mean ( \pm S.E.M.) serum ratios of IGF-I to IGFBP-3 at four developmental stages in untreated control females $($ Con; $n=5)$ and females receiving a constant, s.c. infusion of IGF-I (Igf; $n=4$ ).

${ }^{*} P<0.05$ Igf compared with Con at that time point.

Con group. Group differences in serum concentrations of IGFBP-3 showed a similar pattern throughout the study period (Fig. 2, lower panel). Although a developmental increase in serum IGFBP-3 was evident in all animals $\left(\mathrm{F}_{3,24}=45 \cdot 54\right)$, Igf females consistently had higher levels than Con females $\left(\mathrm{F}_{1,8}=5 \cdot 81\right)$. Serum IGFBP-3 was, on average, $25 \%( \pm 10)$ higher in Igf compared with Con females. The ratio of IGF-I to IGFBP-3 was also significantly higher in Igf compared with Con females throughout the course of the study (Fig. 3; $F_{1,8}=35 \cdot 12$ ). Interestingly, this ratio exhibited a significant developmental increase in Con but not in Igf females $\left(F_{3,24}=4 \cdot 27\right)$. The ratio of IGF-I to IGFBP-3 remained relatively constant in Igf females throughout the course of the study.

\section{Effects on maturation}

Long-term administration of IGF-I did not advance the age at menarche $\left(t_{8}=0.46\right)$ but did advance the age at first ovulation in Igf compared with Con females (Table $1 ; t_{8}=2 \cdot 81 ;$ power $=0 \cdot 61$ ). Consequently, the interval between menarche and first ovulation was signifi-

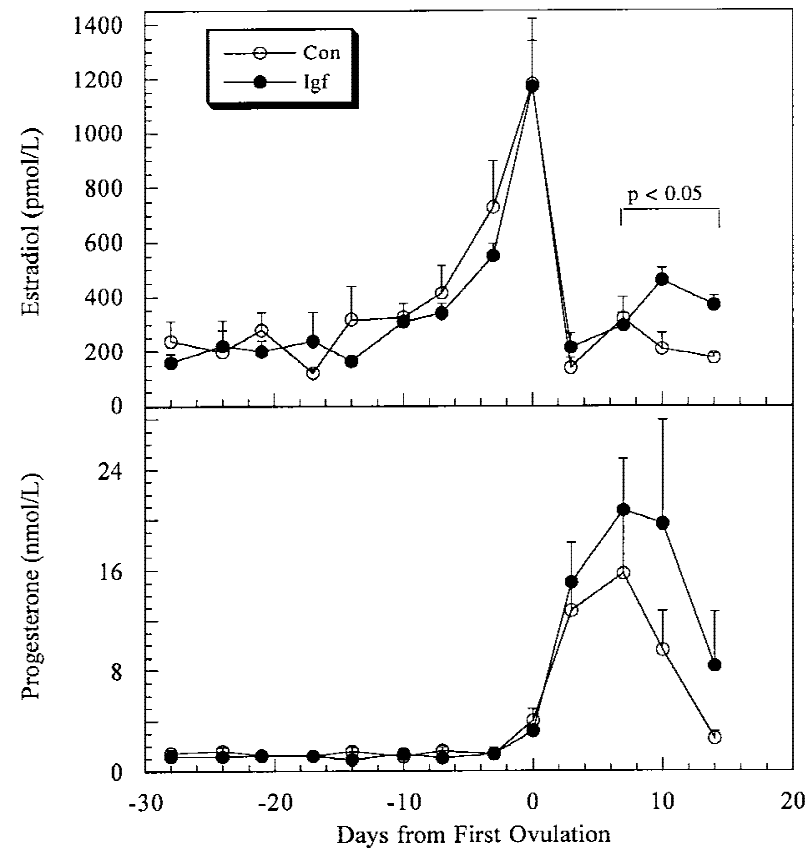

Figure 4 Mean ( \pm S.E.M.) serum concentrations of estradiol (upper panel) and progesterone (lower panel) at first ovulation in untreated control females (Con; $n=6$ ) and females receiving a constant, s.c. infusion of IGF-I (Igf; $n=4)$. Only data from females exhibiting a normal luteal phase are shown. Significant differences between Igf and Con are illustrated by the probability bracket.

cantly shorter in Igf females $\left(t_{8}=2 \cdot 85\right.$; power $\left.=0 \cdot 59\right)$. Although the Con females had fewer ovulations in the 12 months following menarche, the difference was not significant $\left(t_{8}=1 \cdot 11\right)$. However, the percentage of these cycles with normal luteal phase progesterone secretion was greater in Igf females $\left(t_{8}=1 \cdot 72\right.$, one-tailed). Finally, body weights at menarche and first ovulation were similar in Con and Igf females ( $t_{8}=0.74, t_{8}=0.59$ respectively) as was the average monthly gain in weight $\left(t_{8}=0 \cdot 31\right)$.

Using only the data from females having normal luteal phase progesterone concentrations, analysis of serum

Table 1 Maturational parameters (mean \pm S.E.M.) for untreated (Con, $n=6$ ) and IGF-I-treated animals (Igf, $n=4)$

\author{
Maturational event \\ Age at menarche (months) \\ Age at first ovulation (months) \\ Interval from menarche to first ovulation (months) \\ Number of ovulations within 12 months of menarche \\ Percentage normal luteal phase cycles \\ Body weight at menarche $(\mathrm{kg})$ \\ Body weight at first ovulation $(\mathrm{kg})$ \\ Velocity of weight gain $(\mathrm{g} / \mathrm{month})$
}

${ }^{*} P<0 \cdot 05$ compared with Con.

\begin{tabular}{|c|c|}
\hline Con & Igf \\
\hline $23 \cdot 8 \pm 0 \cdot 4$ & $24 \cdot 0 \pm 0 \cdot 3$ \\
\hline $31 \cdot 2 \pm 0 \cdot 3$ & $30 \cdot 0 \pm 0 \cdot 3 *$ \\
\hline $7 \cdot 4 \pm 0 \cdot 4$ & $6 \cdot 0 \pm 0 \cdot 2^{*}$ \\
\hline $3 \cdot 0 \pm 0.5$ & $3 \cdot 8 \pm 0 \cdot 3$ \\
\hline $64 \pm 17$ & $100 \pm 0.00$ \\
\hline $3 \cdot 38 \pm 0 \cdot 16$ & $3 \cdot 59 \pm 0 \cdot 23$ \\
\hline $4 \cdot 52 \pm 0 \cdot 22$ & $4 \cdot 40 \pm 0 \cdot 37$ \\
\hline $4 \cdot 03 \pm 0 \cdot 36$ & $4 \cdot 32 \pm 0 \cdot 28$ \\
\hline
\end{tabular}

Journal of Endocrinology (1998) 158, 247-257

Downloaded from Bioscientifica.com at 04/26/2023 08:04:15AM 
gonadal hormone concentrations at first ovulation (Fig. 4) revealed that levels of estradiol varied significantly throughout the cycle $\left(F_{1,6}=10 \cdot 30\right)$, with higher concentrations observed in Igf compared with Con females during the luteal phase. Serum estradiol concentrations were similar in both groups during the follicular phase. This difference in luteal phase estradiol concentration was also observed during the second ovulation, with significantly higher levels in Igf $(415 \pm 51 \mathrm{pmol} / \mathrm{l})$ compared with Con females $(236 \pm 23 \mathrm{pmol} / \mathrm{l})$. In contrast, serum progesterone was similar in the two groups throughout the first ovulatory cycle $\left(\mathrm{F}_{3,24}=2 \cdot 34\right)$.

The response of serum LH to NMDA was assessed in all subjects prior to menarche ( $\sim 20$ months of age), 2 to 3 months post-menarche, and during either their third ovulation or approximately 50 days after their first ovulation. Importantly, the response to NMDA increased with advancing age in all females (Fig. 5; $\mathrm{F}_{2,16}=5 \cdot 25$; power $=0.75$ ). The difference between Igf and Con females in response to NMDA was evident during the post-menarchial and post-ovulatory assessments $\left(\mathrm{F}_{1,8}=\right.$ 7.07; power $=0.65$ ). Furthermore, the response to the second NMDA injection within each assessment also varied with age and was different between the Con and Igf females $\left(\mathrm{F}_{4,32}=2 \cdot 86\right.$, power $\left.=0 \cdot 71\right)$ : during the premenarche assessment, both the Con and Igf females responded to the first but not the second NMDA treatment. In contrast, at the post-menarche and postovulation assessments both groups responded to each NMDA treatment but the increase in serum LH was significantly greater in Igf compared with Con females.

Changes in serum LH following treatment with the LHRH analog, Lupron, were similar in Con and Igf females (Fig. 6). Although baseline concentrations of serum LH were significantly higher in Igf compared with Con females $\left(\mathrm{F}_{1,8}=5 \cdot 09\right.$, power $\left.=0 \cdot 50\right)$, the increase in serum LH following Lupron was similar in the two groups $\left(F_{8,64}=<1 \cdot 00\right)$. Serum LH peaked at $+3 \mathrm{~h}$ following the administration of the analog, returning to pre-treatment concentrations by $9-12 \mathrm{~h}$ in both groups of animals.

\section{Discussion}

The results of the present study indicate that the experimental elevation of peripheral concentrations of IGF-I has no effect on the timing of menarche but advances the age of first ovulation in female rhesus monkeys. This acceleration was associated with an increased responsiveness of LH secretion to NMDA stimulation. In contrast, the sensitivity of the pituitary to LHRH stimulation was not affected by IGF-I treatment. Furthermore, females receiving IGF-I had a greater incidence of normal luteal phase ovulations, defined by the pattern of serum progesterone, in the 12 months following menarche than did untreated females. In addition, luteal phase estradiol concentrations

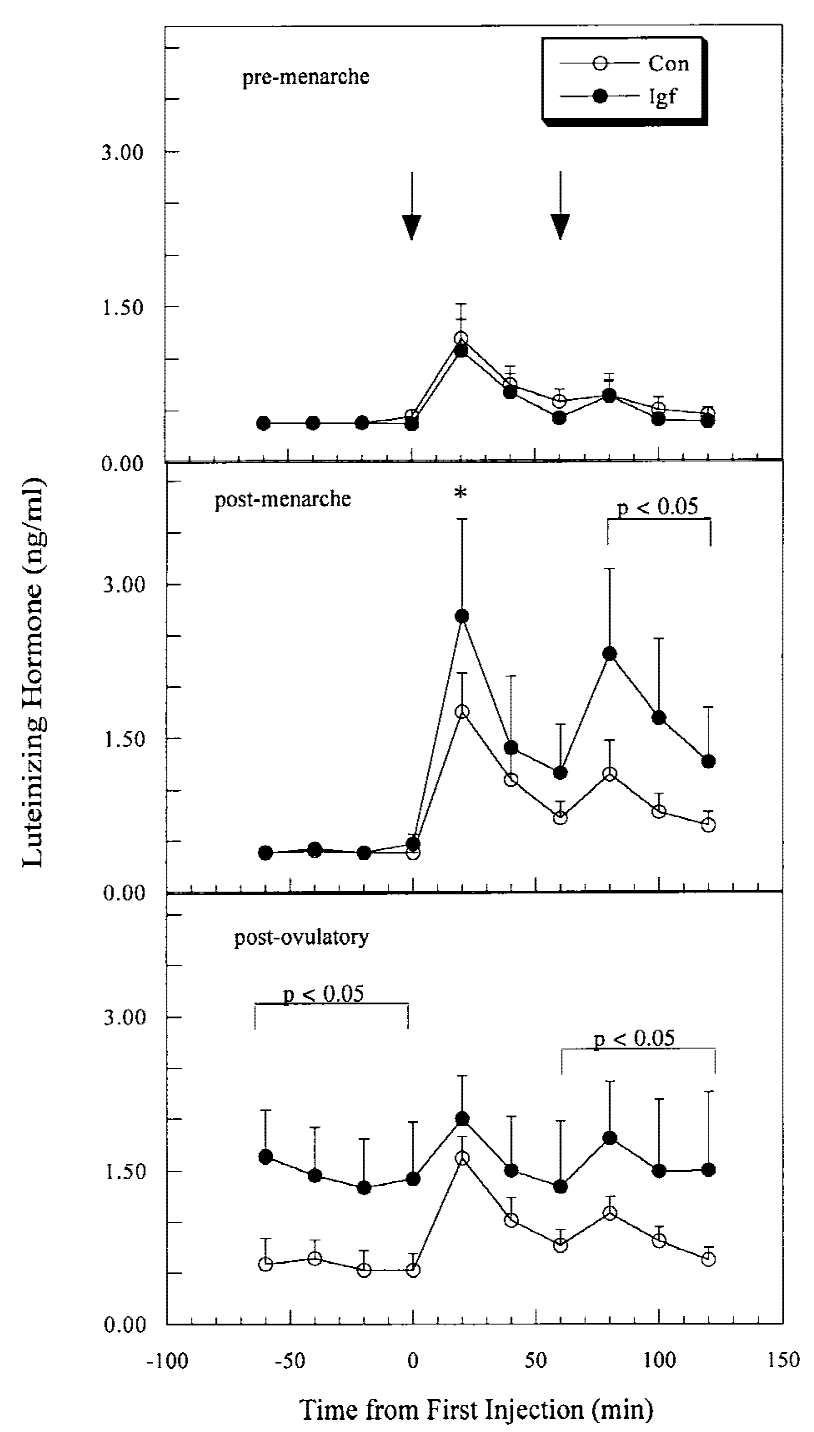

Figure 5 Mean ( \pm S.E.M.) serum concentrations of $\mathrm{LH}$ in response to the administration of NMDA at three developmental stages in untreated control females (Con; $n=6$ ) and females receiving a constant, s.c. infusion of IGF-I (Igf; $n=4)$. NMDA ( $5 \mathrm{mg} / \mathrm{kg}$, i.v.) was administered at time 0 and +60 min (indicated by the arrows). ${ }^{*} P<0.05$ Igf compared with Con at the 0 time point. Other significant differences between Igf and Con are illustrated by the probability brackets.

in these normal ovulatory cycles were consistently higher in IGF-I-treated females compared with untreated animals.

The significantly shorter interval between menarche and first ovulation, resulting in an earlier age at first ovulation, suggests that IGF-I affects those mechanisms regulating $\mathrm{LHRH}$ and $\mathrm{LH}$ secretion during the final stages of puberty. This hypothesis is supported by the observation that IGF-I enhanced the response of serum LH to NMDA stimulation following menarche but not before. These data 


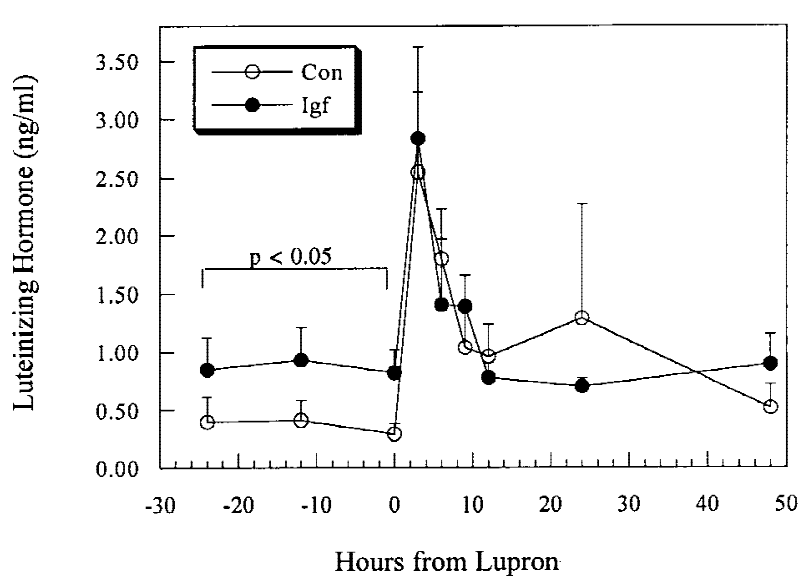

Figure 6 Mean ( \pm S.E.M.) serum concentrations of LH in response to the administration of an LHRH agonist in untreated control females (Con; $n=6$ ) and females receiving a constant, s.c. infusion with IGF-I (Igf; $n=4)$. The LHRH agonist (Lupron; $14 \mu \mathrm{g} / \mathrm{kg}$, s.c.) was administered at time 0 . Significant differences between Igf and Con are illustrated by the probability bracket.

complement earlier studies in monkeys which found that thrice weekly GH injections advance first ovulation but not menarche (Wilson et al. 1989) while the long-term administration of a somatostatin analog, which decreases endogenous GH and IGF-I secretion, delays first ovulation (Wilson \& Tanner 1994). In addition, IGF-I diminishes the hypersensitivity to estradiol negative feedback inhibition of LH secretion in steroid-treated, ovariectomized monkeys (Wilson 1995), a characteristic of late adolescence in monkeys (Rapisarda et al. 1983, Wilson 1995). Although IGF-I increases LH secretion in peri-pubertal, intact rats (Hiney et al. 1996), studies have not examined specifically how IGF-I may modify gonadal steroid negative feedback at first ovulation in this species. However, GH deficiency enhances testosterone negative feedback inhibition of LH secretion in adult mice, an effect reversed by the administration of $\mathrm{GH}$ and the resulting increase in IGF-I (Chandrashekar \& Bartke 1993). Taken together, these data suggest that the post-menarchial increase in GH-dependent IGF-I concentrations sets the tempo for the later stages of puberty, determining the occurrence of first ovulation in monkeys.

In contrast to the results obtained in the present study, attempts to evaluate the role of IGF-I on the completion of puberty in rats have produced negative results. Vaginal opening was delayed by several days when serum IGF-I was suppressed to $>85 \%$ of normal females but was unaffected when serum IGF-I concentrations were, on the average, 50 to $80 \%$ lower than those of controls (Gruaz et al. 1994). In a study similar to the present analysis, subcutaneous infusion of IGF-I to normal rats did not advance the age at vaginal opening, despite an elevation in serum IGF-I greater than $96 \%$ of that of untreated animals (Gruaz et al. 1997). Serum IGFBP-3 levels were also increased by this IGF-I infusion but the ratio of IGF-I to IGFBP-3 was similar to that of untreated control rats, regardless of the IGF-I dose used. In the present study, IGF-I infusion to juvenile monkeys also increased serum IGFBP-3. However, unlike the data from rodents, this increase was not proportional to the elevation in serum IGF-I as the ratio of IGF-I to IGFBP-3 was consistently higher in treated compared with untreated animals. A similar increase in the IGF-I to IGFBP-3 ratio is also observed in IGF-I-treated ovariectomized juvenile females (Wilson 1997). Although this ratio of IGF-I to IGFBP-3 increased developmentally in control females, the ratio in IGF-I-treated females was significantly greater throughout maturation and did not change. Available data suggest that IGFBP-3 acts to increase the bioavailability of IGF-I by slowing degradation (Froesch et al. 1994). Indeed, IGF-I therapy to children with GH receptor deficiency produces more growth if IGFBP-3 concentrations do not increase proportionately to the elevation in IGF-I (Guevara-Aguirre et al. 1995, Ranke et al. 1995). In order to reconcile the differences between the present study and that in rodents on the effects of IGF-I on the completion of puberty (Gruaz et al. 1997), more data are needed evaluating how IGFBP-3 affects IGF-I-IGF receptor interactions.

Acute administration of NMDA provided data on the developmental increase in activity of LHRH neurons (Brann 1995). Indeed, the activation of glutamate receptors has been implicated as a possible mechanism regulating the development of LHRH release (Plant et al. 1989, Urbanski \& Ojeda 1990) and NMDA induces LH secretion in monkeys via activation of LHRH neurons and not through any direct action on the pituitary (Gay \& Plant 1987, Plant et al. 1989). However, the ability of NMDA to induce an immediate release of $\mathrm{LH}$ is dependent upon previous LHRH stimulation of the pituitary and the up-regulation of LHRH receptors (Gay \& Plant 1987). Since glutamate receptors are not found on LHRH neurons but are co-localized with LHRH neurons throughout the mediobasal hypothalamus in the monkey (Goldsmith et al. 1994), the stimulation of LHRH release by NMDA results from a general excitation of interneuronal circuits near the median eminence (Plant et al. 1989, Abbud \& Smith 1995). Given these assumptions, we hypothesized that, if IGF-I was having an effect on LHRH neurons, a greater increase in serum LH would be observed following NMDA administration in IGF-Itreated monkeys. The observation that serum LH was increased in IGF-I-treated monkeys following menarche supports this hypothesis and suggests that the premature elevation in IGF-I accelerated the activation of LHRH neurons which eventually led to an earlier age at first ovulation. In support of the hypothesis that IGF-I either directly or indirectly stimulates LHRH neurons, IGF-I induces LHRH release from the rat median eminence in vitro (Hiney et al. 1991) and the immunoneutralization 
of LHRH blocks the IGF-I-induced increase in serum LH in juvenile and peripubertal rats in vivo (Hiney et al. 1996). In contrast, IGF-I inhibits LHRH-stimulated release from hypothalamic explants of peripubertal rats in a dosedependent manner (Bourguignon et al. 1993). However, since these explants included the arcuate and ventromedial nuclei as well as the median eminence, these contrasting effects of IGF-I on LHRH release may be the result of IGF-I stimulation of different neuronal sub-populations. Only additional studies can reconcile these differences.

IGF-I treatment did not affect the response of the pituitary to stimulation by a long-acting LHRH agonist. However, other studies have shown that IGF-I increases LHRH-stimulated release of LH from pituitary cell cultures (Soldani et al. 1994). Since pituitary responsiveness to LHRH is primarily regulated by previous LHRH exposure and the up-regulation of LHRH receptors (Wildt et al. 1981), any effects of IGF-I on pituitary responsiveness could be attributed to the increased LHRH activity due to IGF-I. In addition to these hypothalamic-pituitary effects, IGF-I can increase the ovarian response to gonadotropin stimulation (see Giudice 1992 for a review). The adolescent monkeys treated with IGF-I in the present study exhibited higher luteal phase estradiol levels at the first and second ovulations. These data complement an earlier report in monkeys that a somatostatin analog reduces serum estradiol concentrations during the luteal phase, even in the presence of normal serum progesterone concentrations (Wilson \& Tanner 1994). Consequently, it is not surprising that the augmentation of $\mathrm{LH}$ secretion and ovarian responsiveness by IGF-I is associated with a greater proportion of normal luteal phase cycles and suggests that the hypothalamic-pituitary effects of IGF-I may facilitate fertility in developing monkeys (Wilson \& Tanner 1994).

If IGF-I facilitates LH secretion during the final stages of puberty, it must be shown to affect those mechanisms that mediate estradiol negative feedback inhibition prior to first ovulation. However, those neuroendocrine mechanisms themselves are still undefined. In adult animals, gonadal steroids inhibit LH secretion by decreasing the activity of neurons in the mediobasal hypothalamus (O'Bryne et al. 1993), resulting in a decrease in LHRH biosynthesis (Toranzo et al. 1989) and release (Karsch et al. 1987). Since LHRH neurons do not contain estrogen receptors, these inhibitory effects of estradiol on LHRH biosynthesis and release are complex and probably involve an interneuronal pathway (Herbison et al. 1995, Sullivan et al. 1995), possibly the activation of the inhibitory neurotransmitter $\gamma$-aminobutyric acid (GABA) in discrete hypothalamic neurons (Herbison et al. 1991, McRee \& Meyer 1993). The expression of estrogen receptors on GABAergic and glutamate neurons increases developmentally in female monkeys (Thind \& Goldsmith 1997). Furthermore, GABA concentrations in the stalk median eminence decrease from prepuberty in female monkeys and the ability of GABA antagonists to stimulate LHRH release is developmentally related to endogenous GABA concentrations (Mitsushima et al. 1994). Since direct synaptic interactions between GABA and LHRH neurons have not been identified in monkeys, the effects are thought to be mediated through interneuron circuits and probably involve reciprocal interactions between GABAglutamate (Thind \& Goldsmith 1995) and glutamateLHRH neurons (Goldsmith et al. 1994). Consequently, the adolescent hypersensitivity to estradiol negative feedback suppression of LH secretion may be the result of an increased GABAergic inhibition of glutamate receptor excitation of LHRH neurons. Although the specific hypothalamic distribution of IGF-I receptors has yet to be described in primates, IGF-I receptors in rats are found in the median eminence (Lesniak et al. 1988, Werther et al. 1989, Aguado et al. 1993) and IGF-I receptor mRNA in this region increases prior to first proestrus in rats (Hiney et al. 1996). Co-localization and functional analysis studies of neurons containing IGF-I receptors and those immunoreactive for GABA and/or glutamate may help determine whether IGF-I diminishes estradiol-induced activation of GABAergic inhibition of glutamate neurons.

In addition to these effects, IGF-I may affect developmental changes in LHRH by a glial-mediated mechanism. Glial cells in the median eminence contain estrogen receptors (Langub \& Watson 1992) and the degree of glial apposition to LHRH neurons is decreased by estradiol treatment in adults (Witkin et al. 1991) and decreases developmentally in monkeys (Witkin et al. 1995). Glialderived transforming growth factor alpha (TGF- $\alpha$ ), acting through the epidermal growth factor receptor (EGF-r) on astrocytes stimulates LHRH secretion (Ma et al. 1997) and the expression of the mRNA for TGF- $\alpha$ (Ma et al. 1992) and the EGF-r (Ma et al. 1994a) in the medial basal hypothalamus increases developmentally in rats and following menarche in monkeys (Ma et al. 1994b). Although the factors responsible for these changes are not known, neurotropic effects of IGF-I may be involved. Glial cells contain IGF-I receptors (Garcia-Segura et al. 1996) and estradiol increases the uptake of IGF-I by glial cells in the mediobasal hypothalamus of developing rats (Duenas et al. 1994). Finally, IGF-I acting through the IGF receptor has been shown to synergize with EGF to increase growth of astroglia cells in vitro (Han et al. 1992). Consequently, IGF-I may augment the developmental increase in LHRH via the maturation of TGF- $\alpha-E G F-r$ system. In this regard, the decrease in adolescent hypersensitivity to estradiol negative feedback by IGF-I would be attributed to the initiation of a stimulatory input to LHRH neurons. These speculations await empirical verification.

The significant acceleration in the age at first ovulation achieved by the premature elevation in serum IGF-I was modest, as was the delay following treatment with the somatostatin analog (Wilson \& Tanner 1994). In another study, the advance in first ovulation in monkeys following the chronic exposure of LHRH neurons to catecholamines 
and neuropeptide Y-producing tissue (Gore et al. 1996) was greater but considerably more variable than the effect produced in the present study. These results underscore the notion that the development of LHRH secretory function is controlled by multiple convergent synaptic inputs and that the simple manipulation of one such system can produce a modest effect on the tempo of puberty. However, manipulations of these systems will lead to a better understanding of what factors regulate LHRH activity and, consequently, fertility. Finally, it was unfortunate and unforeseen that the sample size for the IGF-I-treated group in the present study was reduced by $33 \%$ due to the inefficacy of the IGF-I treatment. Preliminary analysis of these data indicate that this was due to a deficit in serum IGFBP-3 (M E Wilson, unpublished observations). This reduction in sample size certainly reduced the power of the statistical tests evaluating the group differences. A more robust analysis will lend further support to the notion that the developmental increases in IGF-I are important for the attainment of adult reproductive function.

\section{Acknowledgements}

The technical assistance of M Lindsley, K Chikazawa, and $\mathrm{S}$ Lackey is greatly appreciated. The recombinant human IGF-I was a generous gift from Genentech Inc. The reagents for the monkey $\mathrm{LH}$ assay and the antibody for the assay of IGF-I were gifts from the National Hormone Pituitary Program, NIH, NIDDK, and the USDA. All assays were performed by Assay Services at the Yerkes Primate Research Center. This research was supported by grant HD16305 and, in part, grant RR00165.

\section{References}

Abbud R \& Smith MS 1995 Do GnRH neurons express the gene for the NMDA receptor? Brain Research 690 117-120.

Aguado F, Rodrigo J, Cacicedo L \& Mellsrom B 1993 Distribution of insulin-like growth factor-I receptor mRNA in rat brain. Regulation in the hypothalamo-neurohypophysial system. Journal of Molecular Endocrinology 11 231-239.

Bourguignon JP, Gerard A, Gonzalez MLA \& Franchimont P 1993 Acute suppression of gonadotropin-releasing hormone secretion by insulin-like growth factor-I and subproducts: an age-dependent endocrine effect. Neuroendocrinology 58 525-530.

Brann DW 1995 Glutamate: a major excitatory transmitter in neuroendocrine relations. Neuroendocrinology 61 213-225.

Chandrashekar V \& Bartke A 1993 Induction of insulin-like growth factor-I secretion alters the hypothalamic-pituitary-testicular function in growth hormone deficient adult dwarf mice. Biology of Reproduction 48 544-551.

Chongthammakun S, Claypool LE \& Terasawa E 1993 Ovariectomy increases in vivo luteinizing hormone releasing hormone release in pubertal but not prepubertal, female rhesus monkeys. Journal of Neuroendocrinology 5 41-50.

Darendelier F, Hindmarsh PC, Preece MA, Cox L \& Brook CGD 1990 Growth hormone increases the rate of pubertal maturation. Acta Endocrinologica 122 414-416.
Duenas M, Luquin S, Chowen JA, Torres-Aleman I, Naftolin F \& Garcia-Segura LM 1994 Gonadal hormone regulation of insulin-like growth factor I immunoreactivity in hypothalamic astroglia of developing and adults rats. Neuroendocrinology 59 528-538.

Froesch ER, Zenobi PD \& Hussain M 1994 Metabolic and therapeutic effects of insulin-like growth factor-I. Hormone Research 42 66-71.

Garcia-Segura LM, Duenas M, Fernandez-Galaz MC, Chowen JA, Argente J, Naftolin F \& Torres-Aleman I 1996 Interactions of the signaling pathways of insulin-like growth factor-I and sex steroids in the neuroendocrine hypothalamus. Hormone Research 46 160-164.

Gay VL \& Plant TM 1987 N-methyl-D, L-aspartate elicits hypothalamic gonadotropin releasing hormone release in prepubertal rhesus monkeys (Macaca mulatta). Endocrinology 120 2289-2296.

Giudice LC 1992 Insulin-like growth factors and ovarian follicular development. Endocrine Review 13 641-669.

Goldsmith PC, Thind KK, Perera AD \& Plant TM 1994 Glutamate-immunoreactive neurons and their gonadotropinreleasing hormone-neuronal interactions in the monkey hypothalamus. Endocrinology 134 858-868.

Gore AC, Saitoh Y \& Terasawa E 1996 Effects of adrenal medulla transplantation into the third ventricle on the onset of puberty in female rhesus monkeys. Experimental Neurology 140172 183.

Gruaz NM, Arsenijevic Y, Wehrenberg WB, Sizonenko PC \& Aubert ML 1994 Growth hormone (GH) deprivation induced by passive immunization against rat GH-releasing factor does not disturb the course of sexual maturation and fertility in the female rat. Endocrinology 135 509-519.

Gruaz NM, d'Alleves, Charney Y, Skotter A, Ekvarn, Frykland L \& Aubert ML 1997 Effects of constant infusion with insulin like growth factor-I (IGF-I) to immature female rats on body weight gain, tissue growth, and sexual function. Endocrine 6 $11-19$.

Guevara-Aguirre J, Vasconez O, Martinez V, Martinez AL, Rosenbloom AL, Diamond FB, Gargosky SE, Nonoshita L \& Rosenfeld RG 1995 A randomized, double blind, placebocontrolled study on safety and efficacy of recombinant human insulin-like growth factor-I in children with growth hormone receptor deficiency. Journal of Clinical Endocrinology and Metabolism $801393-1398$.

Han VKM, Smith A, Myint W, Nygard K \& Bradshaw S 1992 Mitogenic activity of epidermal growth factor on newborn rat astroglia: interaction with insulin-like growth factors. Endocrinology 131 1134-1142.

Herbison AE, Heavens RP, Dye S \& Dyer RG 1991 Acute action of oestradiol on medial preoptic gamma-aminobutyric acid neurons: correlation with oestrogen negative feedback on luteinizing hormone secretion. Journal of Neuroendocrinology 3 101-106.

Herbison AE, Horvath TL, Naftolin F \& Leranth C 1995 Distribution of estrogen receptor-immunoreactive cells in monkey hypothalamus: relationship to neurons containing luteinizing hormone-releasing hormone and tyrosine hydroxylase. Neuroendocrinology 61 1-10.

Hiney JK, Ojeda SR \& Dees LW 1991 Insulin-like growth factor-I: a possible metabolic signal involved in the regulation of female puberty. Neuroendocrinology 54 420-423.

Hiney JK, Srivastava V, Nyberg CL, Ojeda SR \& Dees WS 1996 Insulin-like growth factor-I of peripheral origin acts centrally to accelerate the initiation of female puberty. Endocrinology 137 3717-3728.

Ibanez L, Potau N, Zampolli M, Virdis R, Gussinye M, Carrascosa A, Saenger P \& Vicens-Calvet E 1994 Use of leuprolide acetate response patterns in the early diagnosis of pubertal disorders: comparison with the gonadotropin-releasing hormone test. Journal of Clinical Endocrinology and Metabolism 78 30-35. 
Karsch FJ, Cummins JT, Thomas GB \& Clarke IJ 1987 Steroid negative feedback inhibition of pulsatile secretion of gonadotropin-releasing hormone in the ewe. Biology of Reproduction 36 1207-1218.

Langub MC \& Watson RE 1992 Estrogen receptor immunoreactive glia, endothelia and ependyma in guinea pig preoptic area and median eminence: electron microscopy. Endocrinology 130 364-372.

Lesniak MA, Hill JM, Kiess W, Rojeski M, Pert CB \& Roth J 1988 Receptors for insulin-like growth factors I and II: autoradiographic localization in rat brain and comparison to receptors for insulin. Endocrinology 123 2089-2099.

Ma YJ, Junier MP, Costa ME \& Ojeda SR 1992 Transforming growth factor-gene expression in the hypothalamus is developmentally regulated and linked to sexual maturation. Neuron 9 657-670.

Ma YJ, Hill DF, Junier MP, Costa ME, Felder SE \& Ojeda SR $1994 a$ Expression of epidermal growth factor receptor changes in the hypothalamus during the onset of female puberty. Molecular and Cellular Neurosciences 5 246-262.

Ma YJ, Costa ME \& Ojeda SR $1994 b$ Developmental expression of the genes encoding transforming growth factor alpha and its receptor in the hypothalamus of female rhesus monkeys. Neuroendocrinology $60346-359$.

Ma YJ, Emde KB, Rage F, Wetsel WC \& Ojeda SR 1997 Hypothalamic astrocytes respond to transforming growth factor- $\alpha$ with the secretion of neuroactive substances that stimulate the release of luteinizing hormone releasing hormone. Endocrinology 138 19-25.

McRee RC \& Meyer DC 1993 GABA control of LHRH release is dependent on the steroid milieu. Neuroscience Letters 157 227-230.

Mitsushima D, Hei DL \& Terasawa E 1994 Gamma aminobutyric acid is an inhibitory neurotransmitter restricting the release of luteinizing hormone releasing hormone before the onset of puberty. Proceedings of the National Academy of Sciences of the USA 91 395-399.

O'Bryne KT, Chen MD, Nishihara M, Williams CL, Thalabard JC, Hotchkiss J \& Knobil E 1993 Ovarian control of gonadotropinreleasing hormone pulse generator activity in the rhesus monkey: duration of the associated hypothalamic signal. Neuroendocrinology $\mathbf{5 7}$ 588-592.

Ogilvy-Stuart AL \& Shalet SM 1992 Growth hormone and puberty. Journal of Endocrinology 135 405-406.

Osterud EL, Lackey SL \& Wilson ME 1986 Estradiol increases somatomedin-C concentrations in adolescent rhesus monkeys (Macaca mulatta). American Journal of Primatology 11 53-62.

Pohl CR, deRidder CM \& Plant TM 1995 Gonadal and nongonadal mechanisms contribute to the prepubertal hiatus in gonadotropin secretion in the female rhesus monkeys (Macaca mulatta). Journal of Clinical Endocrinology and Metabolism 80 2094-2101.

Plant TM 1986 A striking sex difference in response to gonadectomy during infantile development in the rhesus monkey (Macaca mulatta). Endocrinology 119 539-545.

Plant TM, Gay VL, Marshall GR \& Arslan M 1989 Puberty in monkeys is triggered by chemical stimulation of the hypothalamus. Proceedings of the National Academy of Sciences of the USA $\mathbf{8 6}$ 2506-2510.

Ranke MM, Savage MO, Chatelain PG, Preece MA, Rosenfeld RG, Blum WF \& Wilton P 1995 Insulin-like growth factor-I improves height in GH insensitivity: two years' results. Hormone Research $\mathbf{4 4}$ 253-264.

Rapisarda JJ, Bergman KS, Steiner RA \& Foster DL 1983 Response to estradiol inhibition of tonic luteinizing hormone secretion decreases during the final stage of puberty in the rhesus monkey. Endocrinology 112 1172-1179.

Soldani R, Cagnacci A \& Yen SSC 1994 Insulin, insulin-like growth factor I (IGF-I) and IGF-II enhance basal and gonadotropinreleasing hormone stimulated luteinizing hormone release from rat anterior pituitary cells in vitro. European Journal of Endocrinology 131 $641-645$.
Stanhope R, Albanese A, Hindmarsh P \& Brook CGD 1992 The effects of growth hormone therapy on spontaneous sexual development. Hormone Research 38 9-13.

Sullivan KA, Witkin JW, Ferin M \& Silverman AJ 1995 Gonadotropin-releasing hormone neurons in the rhesus macaque are not immunoreactive for the estrogen receptor. Brain Research $\mathbf{6 8 5}$ 198-200.

Terasawa E 1995 Control of the luteinizing hormone-releasing hormone pulse generation in non-human primates. Cellular and Molecular Neurobiology 15 141-164.

Terasawa E, Bridson WE, Nass TE, Noonan JJ \& Dierschke DJ 1984 Developmental changes in the luteinizing hormone secretory pattern in peripubertal female rhesus monkeys: comparison between gonadally-intact and ovariectomized animals. Endocrinology 115 $2233-2240$

Thind KK \& Goldsmith PC 1995 GABAergic neurointeractions in the monkey hypothalamus: a quantitative immunomorphological study. Neuroendocrinology 61 471-485.

Thind KK \& Goldsmith PC 1997 Expression of estrogen and progesterone receptors in glutamate and GABA neurons of the pubertal female monkey hypothalamus. Neuroendocrinology 65 314-324.

Toranzo D, Dupont E, Simard J, Labrie C, Couet J, Labrie F \& Pelletier G 1989 Regulation of pro-gonadotropin releasing hormone gene expression by sex steroids in the brain of male and female rats. Molecular Endocrinology 3 1748-1756.

Urbanski HF \& Ojeda SR 1990 A role for N-methyl-D-aspartate (NMDA) receptors in the control of LH secretion and the initiation of female puberty. Endocrinology 126 1774-1776.

Watanabe G \& Terasawa E 1989 In vivo release of luteinizing hormone releasing hormone (LHRH) increases with puberty in the female rhesus monkey. Endocrinology 125 92-99.

Werther A, Hogg A, Oldfield BJ, McKinley MJ, Figdor R \& Medelsohn FAO 1989 Localization and characterization of IGF-I receptors in rat brain and pituitary gland using in vitro autoradiography computerized densitometry. A distinct distribution from insulin receptors. Journal of Neuroendocrinology 1 369-377.

Wildt L, Hausler A, Marshall G, Hutchison JS, Plant TM, Belchetz PE \& Knobil E 1981 Frequency and amplitude of the gonadotropin-releasing hormone stimulation and gonadotropin secretion in the rhesus monkey. Endocrinology 109 376-385.

Wilks JW, Hodgen GD \& Ross GT 1979 Endocrine characteristics of ovulatory and anovulatory menstrual cycles in the rhesus monkey. In Human Ovulation, pp 205-218. Ed ESE Hafez. Amsterdam: Elsevier/North Holland Biomedical Press.

Wilson ME 1989 Relationship between growth and puberty in the rhesus monkey. In Control of the Onset of Puberty III, pp 137-149. Eds HA Delemarre-va de Waal, TM Plant, GP van Rees \& J Schoemaker. Amsterdam: Excerpta Medica.

Wilson ME 1995 IGF-I administration advances the decrease in hypersensitivity to oestradiol negative feedback inhibition of serum LH in adolescent female rhesus monkeys. Journal of Endocrinology 145 121-130.

Wilson ME 1997 Administration of IGF-I affects the GH axis and adolescent growth in normal monkeys. Journal of Endocrinology 153 $327-335$.

Wilson ME \& Tanner JM 1994 Somatostatin analog treatment slows growth and the tempo of reproductive maturation in female rhesus monkeys. Journal of Clinical Endocrinology and Metabolism 79 495-501.

Wilson ME, Gordon TP, Rudman CG \& Tanner JM 1988 Effects of a natural vs artificial environment on the tempo of maturation in female rhesus monkeys. Endocrinology 123 2653-2661.

Wilson ME, Gordon TP, Rudman CG \& Tanner JM 1989 Effects of growth hormone on the tempo of sexual maturation in female rhesus monkeys. Journal of Clinical Endocrinology and Metabolism 68 29-38. 
Winter JSD, Ellsworth L, Fuller G, Hobson WC, Reyes FI \& Faiman C 1987 The role of gonadal steroids in feedback regulation of gonadotropin secretion at different stages of primate development. Acta Endocrinologica 114 257-268.

Witkin JW, Ferin M, Popilskis SJ \& Silverman AJ 1991 Effects of gonadal steroids on the ultrastructure of the GnRH neurons in the rhesus monkey: synaptic input and glial apposition. Endocrinology 129 1083-1092.

Witkin JW, O'Sullivan H \& Ferin M 1995 Glial ensheathment of $\mathrm{GnRH}$ neurons in pubertal rhesus macques. Journal of Neuroendocrinology 7 665-671.
Xiao E, Xia L, Shanen D, Khabele D \& Ferin M 1994 Stimulatory effects of interleukin-induced activation of the hypothalamopituitary-adrenal axis on gonadotropin secretion in ovariectomized monkeys replaced with estradiol. Endocrinology 135 2093-2098.

Received 6 October 1997

Revised manuscript received 27 February 1998 Accepted 27 March 1998 